Illumine Vol. 12, No. 1, 2013

\title{
Romanticizing the LAND: Agriculturally Imagined Communities in Palestine-IsRael
}

\author{
Jennifer Shutek, Simon Fraser University, BA \\ University of Oxford, M.PhIL CANDidate
}

\begin{abstract}
This paper argues that images, and specifically agricultural images, play a significant role in the imaginings of the Israeli and Palestinian communities. Agriculture has symbolic and material value among Palestinians and Israelis, and contributes to identities and land claims made by Zionist and Palestinian organizations. Anderson's discussion of nation building emphasizes the primacy of print in the imagination of a community; this paper highlights non-textual elements of nation building via case studies of the creation and dissemination of propaganda posters by the Jewish National Fund and the Popular Front for the Liberation of Palestine. A survey of propagandistic agricultural images reveals the shared symbols used by Palestinians and Israelis in forging identities and exclusive claims to land. Despite being common symbols from a shared past, agricultural images are crucial in creating and perpetuating a divide between Israelis and Palestinians, and in arguing for organic links between each group and the land of Palestine-Israel.
\end{abstract}

griculture and food are increasingly prevalent themes within
discourses on the Palestinian-Israeli conflict. Cookbooks,
food blogs, documentaries, and films are emerging that focus 


\section{Agriculturally Imagined Communities in Palestine-Israel}

Lemon Tree. This paper argues that images (and more specifically, agricultural images) played a significant role in the imaginings of the Israeli and Palestinian communities. Benedict Anderson's assertions regarding the primacy of print in the imagination of a community deal relatively briefly with non-textual imaginings of nations (such as posters, woodcuts, and radio broadcasts). ${ }^{1}$ This paper attempts to draw attention to non-textual elements of nation building in the context of the Palestinian-Israeli conflict. Tracing the emergence and evolution of agricultural images used for propagandistic and economic purposes reveals the shared symbols used by Palestinians and Israelis in self-identification and their justification of an exclusive claim to land. Despite being common symbols from a shared past, agricultural images were and continue to be crucial in creating and perpetuating a divide between "Israelis" and "Palestinians," and in constructing an argument for an organic link between each group and the land of Palestine-Israel. ${ }^{2}$ These ideas will be explored via case studies of political organizations representing Israelis and Palestinians, specifically the Jewish National Fund and the Popular Front for the Liberation of Palestine.

\section{"A Lemon Grove Between Us"}

Israeli director Eran Riklis' 2008 film Lemon Tree is set in areas of the West Bank and Israel adjacent to the Green Line that divides the two. ${ }^{3}$ Lemon Tree follows the events of a legal case in which the Israeli High Court of Justice ordered the uprooting of an orchard near the house of Israeli Minister of Defense Shaul Mofaz in Judea and Samaria. The

1 Benedict Anderson, Imagined Communities (New York: Verso, 1991). Discussion of the role of non-textual media in the imagination of communities is dealt with cursorily or in footnotes. See, for example, 54, fn 28.

2 I follow Irus Braverman's nomenclature when referring to the area under consideration in this paper. The actual land involved in Palestine-Israel is loosely defined for the purposes of this paper, as the Popular Front for the Liberation of Palestine considers the territory of the state of Israel, the occupied territories, and the kingdom of Jordan to be rightful parts of Palestine. Here, PalestineIsrael approximately refers to the land encompassed by the state of Israel and the occupied territories. See Irus Braverman, Planted Flags: Trees, Land, and Law in Israel/Palestine (New York: Cambridge University Press, 2009), 2. fn 1.

3 Internet Movie Database, "Eran Riklis," accessed March 12, 2012, http://www. imdb.com/name/nm0726954/bio. 
Palestinian owner of the orchard, Zohariya Morshad, filed a petition with the Israeli Supreme Court, and the latter ultimately ruled that sixty of the eighty trees in the orchard would have to be pruned to a height of thirty centimeters. ${ }^{4}$ Thus, while it takes artistic licenses, Lemon Tree is based upon real events.

Lemon Tree follows two parallel stories. The first is that of Mira Navon, wife of the Israeli Defense Minister, whose home abuts a Palestinian orchard. The second is that of Salma Zidane, a Palestinian widow and owner of the orchard, whose social, personal, and economic identity revolves around the lemon orchard planted by her father. The film deals concurrently with alienation and understanding. The central conflict derives from the Israeli Secret Services' assessment that Salma's lemon grove poses a potential security risk to the Israeli Defense Minister and his family, and must therefore be removed. Salma seeks the assistance of Palestinian lawyer Ziad Duad in order to protest this ruling and protect her trees. While the plot is inarguably about two women and the lemon grove that is between them, it is also an allegory for the larger Palestinian-Israeli conflict.

A main theme of Lemon Tree is that Israelis and Palestinians are not inherently antagonistic towards one another. Rather, through decades of official dehumanization and "Othering," both sides have come to believe that living in proximity with one another is incompatible with a peaceful and secure existence. It is only through the humanization of the Other that a potential solution to the Palestinian-Israeli conflict is feasible. Thus, Riklis offers the proverbial olive branch, suggesting that peace between Palestinians and Israelis is eminently conceivable if people on both sides of the conflict are willing to re-evaluate their "truths" about the Other. However, despite this optimistic perspective, Riklis does not ignore or deny the stark realities of the conflict. He provides numerous examples of the difficulties faced in overcoming the divide between Palestinians and Israelis. Three devices assist in illustrating Riklis' engagement with the obstacles to and possible means of attaining peace: the motif of lemons, female subtext, and the epistemological questioning of vision.

Logically, the principal motif in Lemon Tree is the lemon itself; music, dialogue, thematic content, and imagery pertaining to lemons are united through the medium of film to synaesthetically emphasize

4 Braverman, Planted Flags, 138-42. 


\section{Agriculturally Imagined Communities in Palestine-Israel}

the importance of lemons, and, by extension, agriculture. Riklis' use of lemons and orchards to engage with a situation as complex as the Palestinian-Israeli conflict illustrates the observation made by numerous food historians and anthropologists that food is never simply food, but carries multiple meanings and associations. ${ }^{5}$ The film's opening scene is without dialogue, accompanied instead by the song "Lemon Tree." This song nominally references lemons, but is in fact about a love that once existed, was untenable, and is now lost. The "lemon tree, very pretty" has fruit that is "impossible to eat." However, we witness characters consuming the fruit of the lemon tree throughout the entirety of the film. This consumption of the fruit that is initially described as being "impossible to eat" thus subverts a supposed truth that something sour is unpalatable. While, prima facie, the relationships (between Salma and Ziad, Salma and Mira, Mira and Israel Navon, and Palestinians and Israelis more generally) in Lemon Tree seem too fraught with complexity or animosity to be sustained, the tension between what is said about lemons and the fact that they are consumed suggests that culinary creativity can be read allegorically. The mindset of exploration that is perfectly viable in the kitchen (such as tasting unfamiliar foods and fusing different cuisines) is also applicable to interpersonal interactions, and can in fact be metaphorically applied to the conflict between Israelis and Palestinians.

Lemons also act as a physical manifestation of memory and identity. Salma dreams of a time when, as a young girl, her father held her on his shoulders and carried her through the lemon grove. Thus, the lemon grove is far more than an economic asset to Salma: it signifies her childhood, family, and inheritance. Further, Salma's identity, generosity, economic self-sufficiency, and familial memories are inextricably rooted in her possession and cultivation of her lemon trees. Numerous scenes, including the opening scene of the film in which viewers first see Salma, involve her preparing or serving food, which always includes lemons. The orchard permits Salma to

5 Margaret Visser, Much Depends on Dinner (Toronto: McClelland and Stewart Weidenfeld, 1986), 12; Reay Tannahill, Food in History (London: Review, 2002), xiii. David Mas Masumoto writes: "like an additional flavor, meanings are carried with food." Quoted in Michael Owen Jones, "Food Choice, Symbolism, and Identity: Bread-and-Butter Issues for Folkloristic and Nutrition Studies," Journal of American Folklore 120, (Spring 2007), 133. 
extend her generosity and hospitality to both Palestinians and Israelis who visit her. Salma's guests' appreciative comments regarding the quality of Salma's lemonade suggest an almost mystical and mutually nurturing link between Salma and the land, on which her life depends almost as much as do the lives of her trees. The parallel between Salma and Palestinian and Israeli farmers is evident, and she functions as a sort of "every-woman." Palestinians and Israelis alike can relate to her emotional and economic ties to the land. Several Palestinian and Israeli political groups have mobilized such ties, using agriculture and its imagery in their conflict over proprietorship of the land of Palestine-Israel.

Lemon Tree's two female protagonists are portrayed as mirror images of one another. The parallels between Mira and Salma play on heteronormative female spheres of agriculture and domestic duties in order to emphasize the possibility of women as brokers of peace. ${ }^{6}$ Consequently, "normative" or "traditional" features of female identity that have often been interpreted as indicating female oppression (such as performing largely domestic, private tasks, and having a restricted public voice) are assigned new and empowering meanings in the context of the conflict between Salma's network (Salma, her gardener, her lawyer, and her community) and Mira's (the Israeli Defense Minister, Secret Services, and the Israeli Supreme Court). The subtext in the scenes in which Mira and Salma communicate without speaking (the two do not have a single verbal conversation, due at least in part to the fact that Salma speaks Arabic while Mira speaks Hebrew) suggests that they have a far deeper, non-verbal understanding of one another than one might initially assume. Mira and Salma inhabit a conceptual space, which is a non-physical territory in which Palestinians and Israelis can coexist, being for one another "normal neighbours." They are unique in their imagining of a different community that exists outside of the boundaries of the nation.

The emphasis upon non-verbal forms of communication and interaction is both extended and subverted by an emphasis upon

\footnotetext{
6 For a discussion of the relationship between women and agriculture in the Palestinian-Israel conflict, see Ted Swedenburg, Memories of Revolt: The 193639 Rebellion and the Palestinian National Past (Fayetteville: The University of Arkansas Press, 2003), 184-185,187.
} 


\section{Agriculturally Imagined Communities in Palestine-Israel}

vision, in which Riklis constantly reminds viewers that gathering information through sight alone has the potential to provide inaccurate knowledge. While a focus upon vision impairment and surveillance continues to emphasize non-verbal communication, it provides counterexamples to the silent but effective communication between Salma and Mira. Blindness, vision impairment, and surveillance remind the audience that non-verbal communication has the potential to be ambiguous and equivocal, and is not simply or necessarily a method of interaction that transcends the spoken. The inaccurate "truths" that characters "know" about one another are often obtained through visual observations. In Lemon Tree, ocular observations are regularly filtered through objects that impede or distort vision such as curtains, wires, binoculars, sunglasses, window shades, tree branches, webcams, and televisions.

The most obvious source of vision impairment is the Separation Barrier, which is constructed between the homes of the Zidanes and the Navons in order to protect the Defense Minister from the threat of Palestinian attacks. This Separation Barrier, which in reality required the uprooting of thousands of trees, ${ }^{7}$ represents both physical and symbolic blindness. Crucially, this "blindness" is the result of a conscious decision to erect such a barrier that roughly parallels the Green Line surrounding the occupied West Bank. Riklis' portrayal of the construction of the Separation Barrier connotes disruption, dislocation, and wilful mutual ignorance.

Surveillance features prominently in Lemon Tree, and in this case, sight is privileged and thus represents power, knowledge, and control. Viewers often see Salma's lemon grove from the vantage of surveillance cameras that are monitored by the Defense Minister's security guards, or from the viewpoint of the watchtower that is erected in this lemon grove. However, surveillance, too, is obscured by distance, lack of context and contact, and technology. As a result, the information that Israeli security forces have about Salma's lemon grove decontextualizes her home, rendering it simply a security threat as opposed to a complex space to which her sense of self and community are deeply tied. Questioning the validity of sight as a way of obtaining truth has larger implications for non-textual media. Riklis' nuanced treatment of sight and vision at once celebrates non-

7 Braverman, Planted Flags, 136. 
textual, non-oral understanding (such as the silent connection that exists between Mira and Salma) and censures exclusive reliance upon observation as something that can excacerbate misunderstanding and animosity between Israelis and Palestinians by facilitating reductive and superficial knowledge about one another.

"Well, I wish I could be a better neighbour to her, normal neighbour. But I suppose it's a bit too much to hope for. There's too much blood and too much politics, and there's a lemon grove between us." Mira speaks these lines in response to a reporter's question about the decision to uproot Salma's lemon grove. More than just a lemon grove separates these two women, however: decades of propaganda produced by Palestinian, Jewish, and international groups have contributed to a reification of differences between Palestinians and Israelis. The remainder of this paper will attempt to deconstruct the agricultural symbols present in Lemon Tree by tracing their creation and dissemination via visual media.

\section{Jewish National Fund Propaganda}

In order to deconstruct the semiotic meaning of the lemon, it is helpful to concentrate upon agriculturally themed propaganda posters created by Zionist, Palestinian and Israeli organizations. This section focuses upon posters published by the Jewish National Fund (JNF) and the Popular Front for the Liberation of Palestine (PFLP). Over four hundred images (produced by the JNF, PFLP, Democratic Front for the Liberation of Palestine, and citrus exporting companies, as well as images uploaded onto Facebook pages) pertaining to food and agriculture were examined, and over one hundred were closely analysed. ${ }^{9}$

The JNF has historically been a prolific producer of propaganda, and especially of agriculturally themed propaganda. Documents and statements issued by the World Zionist Organization (such as the WZO's proposal for the creation of a British Mandate in Palestine at the Paris Peace Conference) reveal a narrative of a Zionist mission

\footnotetext{
8 Lemon Tree, directed by Eran Riklis (Israel: Heimatfilm/MACT Productions/ Eran Riklis Productions/Riva Filmproduktion, 2008), 1:17:51-1:18:10.

9 This study makes no claims to an exhaustive analysis of posters published by the JNF and PFLP during the twentieth century due to the elusive and ephemeral nature of posters as mediums of communication.
} 


\section{Agriculturally Imagined Communities in Palestine-Israel}

civilisatrice $;{ }^{10}$ posters are the illustrations of this particular narrative of Zionist return and the redemption of the land of Israel. As a result, one can observe the use of Zionist-Israeli propaganda directed at Jews in the Diaspora, Israeli Jews, and members of the international community in order to bolster ideological, political, and economic support for Eretz Israel, in a "large and widespread propaganda network." ${ }^{11}$

Established in 1901 during the Fifth Zionist Congress, the JNF's initial functions were to collect donations and purchase land for Zionist immigrants. ${ }^{12}$ Although a firman (an imperial edict) issued by Ottoman Sultan Abdülhamid II (r. 1876-1909) in 1882 technically prohibited the settlement of Jews in Palestine (while allowing them to settle selectively in other locations in the Ottoman Empire), the vast size of the empire, the relative inefficiency of the Ottoman bureaucracy, and the Ottoman Empire's lack of finances in the late nineteenth and early twentieth centuries rendered this largely unenforceable. ${ }^{13}$ Throughout the early years of the twentieth century, members of the WZO refined the JNF's mandate. The Twentieth Zionist Congress of 1937 assigned to the JNF "responsibility for the vigorous and rapid redemption of new areas of land as a solid foundation for the establishment of the Hebrew homeland." ${ }^{4}$ This mandate united biblical, historical, environmental, and nationalistic sentiments, all of which furthered the cause of the creation of a homeland for Jews in Palestine.

10 "The Zionist Organization's Memorandum to the Peace Conference in Versailles Asks for Support for the Establishment of a Jewish State in Palestine, February 3, 1919," in Akram Fouad Khater, Sources in the History of the Modern Middle East (Houghton Mifflin Harcourt, 2003), 193-200; James Gelvin, The Israel-Palestine Conflict: One Hundred Years of War ( $2^{\text {nd }}$ ed.) (New York: Cambridge University Press, 2007), 66.

11 Yoram Bar-Gal, Propaganda and Zionist Education: The Jewish National Fund 1924-1947 (New York: The University of Rochester Press, 2003), 10. This section relies upon over two hundred posters produced by the JNF over the course of the twentieth century, a close examination of over twenty-five posters that overtly related to agriculture or the land, and perusal of the JNF website.

12 Ibid., 2; Gelvin, The Israel-Palestine Conflict, 63.

13 Gelvin, The Israel-Palestine Conflict, 52-53; Kahraman Sakul, "Abdulhamid I," eds. Gábor Ágoston and Bruce Masters, Encyclopedia of the Ottoman Empire (New York: Facts on File, Inc., 2009), 6.

14 Bar-Gal, Propaganda and Zionist Education, 8. 
From its inception, the JNF was highly involved in the dissemination of propaganda, which aimed to simultaneously bolster both ideological and financial support for the Zionist enterprise. A statement in The JNF Box describes the role of commercial propaganda as follows: "commercial propaganda essentially aspires to achieve the same goal we are trying to achieve, and that is to arouse as many people as possible for a known purpose to do something that they would not have done without the propaganda ... We also wish to cause the large Jewish multitudes to remember the JNF at all times." ${ }^{15}$ Much of the JNF's propaganda was designed by Propagandistim who were educated and spent time on Jewish settlements, and were then sent to the international Jewish Diaspora to disseminate propaganda. ${ }^{16}$ Material symbols such as the Blue Box fundraiser, stamps, filmstrips, the Golden Book, and memorial stones involved and educated Israeli Jews and members of the international Jewish Diaspora in and about the Zionist cause. These symbols were accompanied by another medium of propaganda: the poster. ${ }^{17}$ Many of these posters drew parallels, at times implicit, between the plight of the Jewish Diaspora and the land of Israel via themes of environmental stewardship, land reclamation, and the mutually dependent return of Diaspora Jews and the revitalization of the land.

One JNF poster portraying a cornucopia of food harvested from the land uses overtly biblical rhetoric to justify Jewish rights to the land of Israel. This poster features onions, grapes, olives, wheat, and a fig against a background of a tilled plot of agricultural land. Its caption reads: "the seven-fold blessed land of Israel awaits redemption by the people of Israel through the Jewish National Fund." Thus, the text interweaves stewardship, religious legitimacy, the political state of Israel, and the international organization of the JNF. ${ }^{18}$ This religious claim is bolstered by a seemingly natural ability possessed by Jewish

15 The Blue Box Work: Karnenu, Year 3 (1926), no. 5-6, 5, in Ibid., 12.

16 Ibid.

17 Bar-Gal, Propaganda and Zionist Education, 11; Braverman, Planted Flags, 6270.

18 Franz Krausz (Israeli artist), "The Seven-Fold Blessed Land of Israel Awaits Redemption," poster, ca. 1935, originally published by the Jewish National fund, accessed via the Palestinian Poster Project Archive, accessed February 21, 2012, http://www.palestineposterproject.org/poster/blessed-land-of-israel-awaitsredemption. 


\section{Agriculturally Imagined Communities in Palestine-Israel}

peoples to render the land of Israel abundant and healthy. Numerous posters published by the JNF in the twentieth century stress the positive correlation between the possession and cultivation of the land of Israel by Jews and the redemption of the land that will ensue.

As scholars writing on Zionist settlement have noted, Arabs were seen as usurping and foreign to the land of Israel on one hand, and as an adverse or hostile aspect of the natural environment that had to be tamed or rooted out on the other. ${ }^{19}$ Posters such as the one previously discussed, through conspicuous omission, suggest that "the redemption of the land by the people of Israel" is in stark contrast to the desolate wasteland conditions that prevailed under Arab mismanagement. Others, such as a poster in which an image of a desolate wasteland is being pulled off of an underlying image depicting an Israeli settlement abutting fertile and geometrical plots of agriculture, more overtly juxtapose the supposed mismanagement of Palestine-Israel's Arab inhabitants with the efficacious stewardship of Jewish Israelis. ${ }^{20}$ The straight lines used in the JNF's depictions suggest that Jews are not only the most capable of returning fertility and civilization to the land of Israel, but that they are rational and modern in their use of arable land. Again, this implies that, prior to the creation of kibbutzim and moshavim (cooperative agricultural settlements), Arabs were improperly using the land, thus occluding the prosperous agricultural economy of late-Ottoman Palestine. ${ }^{21}$

As Irus Braverman observes, the JNF had a duty to forge and

19 Charles S. Kamen, Little Common Ground: Arab Agriculture and Jewish Settlement in Palestine, 1920-1948 (Pittsburgh: University of Pittsburgh Press, 1991), 18. Uri Eisenzweig writes that, "Zionists would "purely and simply, not see the Arab Palestinians." They could perceive "natives" who, like trees and stones, formed part of the virginal, natural space, but not an Other. These "natives" did not constitute any particular social group, namely Arabs, for, "the vision of natural space, of landscape, is correlative of the absence of otherness." Uri Eisenzweig, "An Imaginary Territory? The Problematic of Space in Zionist Discourse," Dialectical Anthropology 5 (1981): 121-130, cited in Swedenburg, Memories of Revolt, 47.

20 David Zak (Israeli artist), "From a Wasteland to a Settlement," poster, ca. 1935, originally published by the Jewish National Fund, accessed via the Palestinian Poster Project Archive, accessed February 2012, http://www.palestineposterproject. org/poster/from-a-wasteland-to-a-settlement.

21 See Gelvin, The Israel-Palestine Conflict, 25-30 and 69 for a discussion of late Ottoman Palestine's agricultural economy. See also Jaffa, the Orange's Clockwork for an explanation of the mechanisms of erasure of Arab agriculture in the particular case of Jaffa. 
disseminate the idea of an inalienable, mythic, historical, and religious tie between the Jewish people and the land of Israel. ${ }^{22}$ Following the Second World War, the full force of the Holocaust was added to the list of grievances to be remedied by the creation of the state of Israel. The memory of the Holocaust is preserved via museums and memorials. In Palestine-Israel, trees also assist in the commemoration of this significant event in Jewish history. A poster advertising the Forest of the Six Million relies upon mixed media. Its full effect is appreciated at the intersection of the language, through a title that reads "we shall never forget our martyred dead," which depicts Holocaust victims as martyrs, and the image, which conveys ideas of tangible and enduring memorialization of the dead, and Jewish permanence in their homeland. ${ }^{23}$ Because forests require upkeep (watering, fertilizing, pruning, planting, monitoring for fires), the Israeli Jewish community and the Jewish Diaspora can continually contribute to the assertion of Israeli rootedness in Eretz Israel and the commemoration of a shared past of suffering through the care of the trees. This adds to the imagination of a community of suffering which involves all Jews in simultaneous commemoration and shared memories of past trauma.

JNF propaganda posters rely heavily upon the multivocality of trees, which symbolize rootedness, longevity, and memorialization of the dead. It also stakes figurative and physical claims to the land of Israel while drawing parallels between Jewish people and trees, both of which flourish in the soil of Eretz Israel. This conflation of the people and the land is also a common theme within PFLP propaganda, as will be discussed below.

Braverman notes in her introduction that, "national wars are typically associated with soldiers, with blood, and with large flags blowing in the wind. They are not associated with trees or with greening the landscape." ${ }^{24}$ Significantly, this statement refers to national wars, thus establishing agriculture and land ("trees" and "greening the landscape") as facets of the Israeli and Palestinian communities. This paper contends that visual representations of landscape, trees, and

22 Braverman, Planted Flags, 59-63.

23 Unknown Artist, "Forest of the Six Million," poster, ca. 1950, originally published by the Jewish National Fund, accessed via the Palestinian Poster Project Archive, accessed March 11, 2012, http://www.palestineposterproject.org/poster/ we-shall-never-forget-our-martyred-dead.

24 Braverman, Planted Flags, 1. 


\section{Agriculturally Imagined Communities in Palestine-Israel}

agricultural goods in Palestine-Israel were crucial tools of non-textual nation building projects undertaken by various Palestinian and Israeli organizations and, by extension, that non-textual imaginings of the nation were just as crucial as were textual ones in the PalestinianIsraeli conflict.

Propaganda, Poster Making, and the Popular Front for the Liberation of Palestine

PFLP posters relying upon agricultural images generally employ images and symbols that have already been encountered in the previous discussion of JNF propaganda; the PFLP and the JNF both operated and continue to operate within the same symbolic universe. The PFLP was established in 1967 and is a self-proclaimed LeninistMarxist political organization. ${ }^{25} \mathrm{~A}$ reading of its 1969 platform reveals a strong ideological commitment to workers and peasants, and suggests a reason for which agricultural imagery has been so prevalent in the PFLP's posters. ${ }^{26}$ An interview with Doctor George Habash, an Arab Christian medical doctor who was the first Secretary-General of the PFLP, permits a deeper understanding of this party's ideologies. ${ }^{27}$ While disparaging nationalist sentiment as something that subverts class struggle (specifically in the context of Jordanian collusion with Israel), Habash also calls for recognition of the "special characteristics of the Palestinian people, particularly as far as their dispersion and experiences are concerned." ${ }^{28}$ It is this very dispersion that permits Habash to describe the Palestinians and their relationship to the land of Palestine-Israel with agricultural diction, suggesting that Palestinians are akin to indigenous agricultural products on this land.

25 Aaron Mannes, Profiles in Terror: The Guide to Middle Eastern Terrorist Organizations (Maryland: Rowman and Littlefield, 2004), 309-310; Gelvin, The Israel-Palestine Conflict, 203-204.

26 Popular Front for the Liberation of Palestine, "Platform of the Popular Front for the Liberation of Palestine (1969)," accessed March 7, 2012, http:// pflp.ps/english/1969/12/platform-of-the-popular-front-for-the-liberation-ofpalestine-1969/.

27 George Habash, Palestine Lives: Interviews with Leaders of the Resistance (Beirut: Palestine Research Center and Kuwaiti Teachers' Association, 1973); this interview was first published in a 1972 volume of Shu'un Filastinyya.

28 Habash, Palestine Lives, 71-72. This comment is noteworthy for its similarity to descriptions of Jews as a Diaspora group. 
He uses an analogy between plants and people when he states that as long as "there are people in camps, exiled from their land, then there will be revolution. [...] we should [...] not allow ourselves to be attacked or uprooted."29

While Habash's perspective illuminates the theoretical ideology of the PFLP, it does not necessarily reveal the mechanisms by which this organization's posters were designed, created, and disseminated. In order to further deconstruct the creation of PFLP propaganda it is useful to investigate the mechanisms of poster production. However, due to the statelessness of Palestinians and the fact that many Palestinian resistance organizations (including Fatah, the Democratic Front for the Liberation of Palestine, Hamas, and the PFLP) are identified as terrorist organizations, there is a marked lack of easily accessible and verifiable information. ${ }^{30}$ Marc Rudin (a.k.a. Jihad Mansour) is a Swiss-born artist who has produced posters and graffiti for various socialist movements and has designed numerous posters for the PFLP. Extracts from a correspondence with him are available on nadir.org, a German-based left wing website that functions as a database and area of communication, and these permit insight into the actual mechanism of poster production. ${ }^{31} \mathrm{He}$ provides invaluable information regarding the logistics of designing and producing a poster, which include difficulties in obtaining supplies, cramped quarters, and poor communication systems. The PFLP provided him with health care, clothes, rent, a small stipend, and materials to design posters. ${ }^{32}$ From a cultural perspective, Rudin acknowledges the difficulties he faced in employing contextually relevant and appropriate posters:

29 Ibid., 78.

30 Federal Bureau of Investigation, "Terrorism Project: List of Known Terrorist Organizations," last modified January 15, 2009, accessed April 11, 2012, http:// www.cdi.org/terrorism/terrorist-groups.cfm.

31 Nadir.org; Donatella Della Porta, Globalization from Below: Transnational Activists and Protest Networks (Minnesota: Regents of the University of Minnesota, 2006), 112. Here, nadir.org is described as an organization that promotes "alternative and critical information."

32 Marc Rudin, (Swiss artist), accessed March 4, 2012, http://www.nadir.org/ nadir/initiativ/rev_linke/sanat/jihad/jihad.html. 


\section{Agriculturally Imagined Communities in Palestine-Israel}

Of course I had to learn a lot of things, as the symbols or even the symbolic aspects of colours for instance differ from one culture to another. In 1980 I designed a poster for Labour Day with dominant green colours. I was harshly criticized by a young fighter that green was the colour of Islam and that we were no fundamentalists. In his opinion the colour of green had therefore nothing to do on a Labour Day poster, a fact I had not taken into account with my cultural background. ${ }^{33}$

Rudin identifies the assumptions and potential miscommunications that are involved in viewing symbolic work produced within another cultural context as major obstacles when using posters as a lens through which to view popular culture and popular consciousness. Attempting to interpret such works, and drawing conclusions about the ideas and ideologies of those who view and engage with the artwork in question, are also critical concerns. Rudin cites feedback from Shabiba, a Palestinian youth organization, as being significant and valuable in his design process. These Palestinian youth not only helped Rudin construct an understanding of the larger Palestinian population, but also provided the mechanism by which his propaganda posters were actually distributed throughout Palestinian communities. ${ }^{34}$ Rudin notes another difficulty of communicating the messages of the PFLP via posters: the challenge of condensing a complex set of values into one or two easily recognizable images without being overly reductive. ${ }^{35}$ A closer look at several posters published by the PFLP reveals tropes that are employed in its agriculturally themed propaganda, and helps us to understand how the PFLP addressed some of the difficulties inherent in the use of posters to convey messages of resistance, revolution, and solidarity.

A 1985 poster produced by the PFLP and designed by Marc Rudin observes Martyr's Day. ${ }^{36}$ In it, a pair of hands holds up a framed picture of a kuffiyah, a cotton headdress iconographically associated

33 Ibid.

34 Ibid.

35 Ibid.

36 Marc Rudin, “Martyr’s Day," poster, 1985, originally published by the Popular Front for the Liberation of Palestine, accessed via Palestinian Poster Project Archive, accessed February 3, 2012, http://www.palestineposterproject.org/ poster/palestine-will-win- 0 . 
with the Palestinian people. In place of a face, however, there is fecund orange tree. Rifle tips emerging from the bottom of the poster belie the message of purely peaceful resistance, reminding viewers of what George Habash described as the "fundamental importance" of "revolutionary violence." This image powerfully conflates the land and its agricultural abundance with Palestinians and their revolutionary liberation cause. This poster also evokes the viewer's memory, as its commemoration of Martyr's Day invites people to remember what has been lost. Due to the conflation of Palestinians and the land, it becomes impossible to commemorate the loss of people without simultaneously recalling the loss of a homeland. This poster highlights the need for poster artists to have fairly extensive cultural capital.

A poster designed for Land Day, 1981, contains multiple symbolic layers. ${ }^{37}$ It features a tree in the shape of the state of Israel, which has roots that extend deep into the earth. This tree is not only embedded into the soil of the land, but is bountiful, producing numerous leaves that bear the same colours and design as the Palestinian flag. While clarification is offered by the poster's bilingual Arabic-English text ("Land Day" is written in both Arabic and English) indicating that it has been specifically produced for Land Day, the fundamental messages communicated in this image are not restricted to the literate (hence exemplifying a non-textual imagining of the Palestinian community). The tripartite themes of rootedness, statehood, and Palestinian identity clearly convey the notion that Palestinians naturally and organically exist in symbiosis with the land of presentday Israel. While Palestinians belong to and rely upon the land, the land is only truly fruitful when they are planted in it.

The images that have been so frequently employed by both the JNF and the PFLP during the twentieth century have carried through into the twenty-first century. However, especially in the wake of the massive networks of communication facilitated by the internet, these images are being conveyed in different forums. Aside from being disseminated via online social networks, blogs, magazines, and websites, agricultural and food-related images are being imbued

37 Kamal Nicola (Palestinian artist), “Land Day," poster, 1981, originally published by the Popular Front for the Liberation of Palestine, accessed via Palestinian Poster Project Archive, accessed February 8, 2012, http://www.palestineposterproject. org/poster/land-day-pflp. 


\section{Agriculturally Imagined Communities in Palestine-Israel}

with new meanings that are consistent with the realities of a world in which people increasingly inhabit urban areas.

\section{Cuisine and Constructions of Identity}

This paper will return to the tensions of the twenty-first century by discussing the use of agricultural images as metonyms for the supposedly mutually exclusive and hostile Palestinian and Israeli sides of the conflict that create and reinforce the idea that two distinct and oppositional sides exist. When looking at images procured from Facebook, it will be crucial to consider the "blogosphere" an open and largely anonymous domain on which anybody can post images without needing to authenticate their content or sources. It thus has the potential to be much more democratic and grassroots than does scholarship, and at the same time can be fraught with issues of legitimacy, authority, and representation.

Contemporary Palestinians and Israelis still engage and identify deeply with agricultural symbols. An examination of two open Facebook groups dedicated to food or agriculture reveals how successfully images of agricultural products have entered into Palestinian and Israeli discourses of identity. It is this entry of agricultural images into popular culture that gives lemons in Lemon Tree their rich symbolic value. Online Facebook groups and blogs dedicated to food or agriculture reveal that, at least to some extent, the images associated with Israeli and Palestinian national identities have entered into the "popular nationalism" 38 (grassroots, and hence not necessarily uniform, nationalistic ideas held by a group of people) of contemporary members of both of these groups. The Facebook group "Palestinian Food," which has over seventy-eight thousand members (most of whom live in Jordan and are likely members of the Palestinian diaspora), contains numerous pictures of olive oil, olives, dishes featuring lemon wedges, oranges, and orange juice, inter alia. Interspersed with culinary photographs are numerous images of fruit-bearing trees, the Palestinian landscape, Palestinians wearing traditional clothing, and images of the Palestinian flag, all of which reinforce links between Palestinians and the land in the popular imagination.

38 Swedenburg, Memories of Revolt, 76. 
The JNF Facebook page makes overt use of twentieth-century agricultural propaganda images and has a membership of over fortythree thousand. Its photographs relate predominantly to raising funds for tree planting, parks and recreation areas in Israel, and celebrities planting trees in Israel. The page portrays agricultural and landscaping aspects of the Israeli state as authentic, modern, and enjoying the ideological support of the international community. The number of "likes" that the JNF Facebook page receives is used to assert domestic and international support for the ideology and actions of the JNF. The JNF Facebook page celebrates landmarks (such as receiving 15,000 "likes") by posting an image of a hand holding soil and a growing tree alongside the number of current "likes" for the page. ${ }^{39}$

\section{Conclusion}

Riklis' Lemon Tree causes viewers to reflect upon the significance of the lemon: why is this fruit so laden with symbolism, and what historical and cultural factors act upon its significance? The lemon's semiotic value in this film can be understood via a deconstruction of a century of agriculturally themed propaganda relied upon by both Palestinian and Israeli organizations and companies, as is evidenced by an examination of several posters produced by the JNF and the PFLP. One of the most striking aspects of their agriculturally themed propaganda is a common visual-symbolic vocabulary. Both organizations employ images of olives, trees, oranges, lemons, flowers, and agricultural cultivation to assert their unique right to the land, with an implied contradistinction to the lack of legitimacy that the "Other" has in claiming the same land. The very fact that both sides are appropriating the same images to justify their claims to the land of Palestine-Israel has several implications. First, the JNF and the PFLP both employ imagery that suggests shared values: the importance of the land and cultivation, the organic and symbiotic ties between people and the land, and a desire for autonomy and the ability to live life without threats to one's health, livelihood, family, or community. Second, the differences and hostilities between these two

39 See Jewish National Fund (Facebook page), accessed April 19, 2012, https:// www.facebook.com/jewishnationalfund. 


\section{Agriculturally Imagined Communities in Palestine-Israel}

communities are not primordial or inevitable, but rather aspects of life that have emerged relatively recently and have been emphasized by political organizations in order to bolster their arguments for exclusive rights to the land of Palestine-Israel.

Although many observers of the Palestinian-Israeli conflict despair of a viable solution, a discourse in which "Palestinians" and "Israelis" do not, in fact, comprise monolithic, homogenous, and mutually hostile entities does exist. Films such as Lemon Tree suggest that some artists and academics are in the process of exploring and disseminating perspectives on the conflict that subvert notions of inevitable conflict, creatively contributing to this discourse that sees potential for cooperation and coexistence between the various groups of people living in Palestine-Israel. ${ }^{40}$ Engagement with this discourse occurs outside of academic and artistic spheres, as well. Several grassroots movements currently exist that involve Palestinians, Israelis, and members of the international community who are working towards a peaceful coexistence. One of these is the Olive Tree Campaign, an initiative led by the East Jerusalem YMCA and the YWCA of Palestine. This initiative engages with financial donors and volunteers on an international scale to plant olive trees on the land of selected Palestinian farmers whose orchards have been uprooted by the Israeli military, as well as to assist with the annual olive harvest that takes place in late October. ${ }^{41}$

Agriculture and landscape are tools, soldiers, and arenas of conflict in the ideological and physical dispute between those who have supported Zionism and those who have opposed it. ${ }^{42}$ This is not to negate a materialist understanding of the conflict by implying that agriculture and landscape did not have any tangible importance, or that these were simply tools of political machinations bent upon gaining power. To the contrary, much of the symbolic weight

40 See also the documentary Jaffa, the Orange's Clockwork, directed by Eyal Sivan (Tel Aviv: Trabelsi Productions,

2010), for an in-depth discussion of the use of images to erase Arab presence in Palestine-Israel and to market commodities to an international community via Orientalism.

41 Joint Advocacy Initiative: The East Jerusalem YMCA and YWCA of Palestine, "Olive Tree Campaign: The Ninth Season 2010-2011 (an annual report on plan and implementation of olive tree planting campaign)," (Jerusalem, 2010).

42 Gelvin, The Israel-Palestine Conflict, 2-3; Braverman, Planted Flags, 47-57. 
attached to agriculture stems from its importance in the livelihoods of Palestinians. Today, over 70,500 farmers living in the occupied Palestinian territories own olive trees, and an increasing number of Palestinians are becoming reliant upon agricultural production as a source of income and for subsistence. ${ }^{43}$ Therefore, agriculture endures as an important facet of quotidian lives and has symbolic and material value. It contributes materially and ideologically to identities and claims to land that are disseminated by Zionist and

Palestinian organizations.

Attempting to deconstruct competing nationalist narratives and refuting notions of "Palestinian" and "Israeli" nations certainly does not undermine people's claims to land, food, shelter, freedom, and respect, as is evidenced by organizations such as the Olive Tree Campaign and the Coalition of Women for Peace. ${ }^{44}$ If anything, a deconstruction of various national identities can facilitate a reconceptualization of "Israelis" and "Palestinians" as members of a regional community. The examination of images reveals two groups, vociferously arguing for their uniqueness, who appeal to shared agricultural symbols and values to make these claims. Lemon Tree illuminates the role that food and agriculture can play in humanizing Palestinians and Israelis, breaking down rigid binaries that have been promoted, ironically via images of food and agriculture, in JNF and PFLP propaganda throughout the twentieth century.

Reflecting upon Arab-Jewish relations during the early twentieth century, Gideon Makoff, the Jewish General-Secretary of Pardes cooperative, a fruit-exporting cooperative that operated near Tel Aviv, recalled that, "they [Arabs] lived off us, and us off them, simple ... so we gave one another life." 45 Makoff's recollection of Arab-Jewish relations at the time of the first and second aliyot (literally, "ascensions," in reference to waves of Jewish migration to Palestine) subverts the narrative used by both the JNF and the PFLP, albeit with different characters according to the organization. From Jewish agricultural

43 Braverman, Planted Flags, 122-123.

44 The Coalition of Women for Peace is a feminist organization involving Israeli and Palestinian women working together to raise awareness about the Israeli occupation and advocate a just peace between Palestinians and Israelis. "About CWP," accessed April 5, 2012, http://www.coalitionofwomen.org/?page_ $\mathrm{id}=340$ \&lang $=$ en.

45 Gideon Makoff, in Jaffa, the Orange's Clockwork, 19:49-20:12. 


\section{Agriculturally Imagined Communities in \\ Palestine-Israel}

propaganda posters, viewers see that Jews and the land of PalestineIsrael work symbiotically with one another. The same conclusion can be drawn about Palestinians from the PFLP's agriculturally themed propaganda. However, according to memories of people like Makoff, the true symbiosis has historically been, and can be again, between the Palestinian and Israeli people themselves.

\section{Bibliography}

Anderson, Benedict. Imagined Communities. New York: Verso, 1991.

Bar-Gal, Yoram. Propaganda and Zionist Education: The Jewish National Fund 1924 1947. New York: The University of Rochester Press, 2003.

Braverman, Irus. Planted Flags: Trees, Land, and Law in Israel/ Palestine. New York: Cambridge University Press, 2009.

Brownsell, James. "Resistance is Fertile: Palestine's Eco-War." Al Jazeera English, last modified November 1, 2011, http://www. aljazeera.com/indepth/features/2011/08/2011823152713716742. html.

Cuddon, J. A. Dictionary of Literary Terms and Literary Theory. (4 $4^{\text {th }}$ ed.) New York: Penguin Group (USA) Inc., 1998.

Della Porta, Donatella. Globalization from Below: Transnational Activists and Protest Networks. Minnesota: University of Minnesota, 2006.

Federal Bureau of Investigation. "Terrorism Project: List of Known Terrorist Organizations," last modified January 15, 2009, http:// www.cdi.org/terrorism/terrorist-groups.cfm. 
Unknown Artist, "Forest of the Six Million." Poster. ca. 1950, originally published by the Jewish National Fund. Accessed via the Palestinian Poster Project Archive, http://www. palestineposterproject.org/poster/we-shall-never-forget-ourmartyred-dead.

Gelvin, James L. The Israel-Palestine Conflict: One Hundred Years of War. ( $2^{\text {nd }}$ ed.) New York: Cambridge University Press, 2007.

Green Olive Tours. "Al Jazeera Features Green Olive Tours," last modified January 2, 2012, http://blog.toursinenglish. com/2012/01/al-jazeera-features-green-olive-tours. html.

Israel Film Center. "Eran Riklis," last modified 2012, http:// www.israelfilmcenter.org/viewing-library/filmmakers/eranriklis.

Jaffa, the Orange's Clockwork. Directed by Eyal Sivan. Tel Aviv: Trabelsi Productions, 2010.

Jewish National Fund (Facebook page).

https://www.facebook.com/jewishnationalfund.

Joint Advocacy Initiative: The East Jerusalem YMCA and YWCA of Palestine, "Olive Tree Campaign: The Ninth Season 2010-2011 (an annual report on plan and implementation of olive tree planting campaign)," (Jerusalem, 2010).

Jones, Michael Owen. "Food Choice, Symbolism, and Identity: Bread-and-Butter Issues for Folkloristic and Nutrition Studies." Journal of American Folklore 120: 476 (Spring 2007), 129177. http://dx.doi.org/10.1353/jaf.2007.0037

JustSeeds Artists' Cooperative. "Lists: Twenty Poster Books of Note," last modified September 2009, http://www.justseeds.org/ blog/2009/09/lists_a_dozen_poster_books_of.html. 


\section{Agriculturally Imagined Communities in}

\section{Palestine-Israel}

Kamen, Charles S. Little Common Ground: Arab Agriculture and Jewish Settlement in Palestine, 1920-1948. Pittsburgh: University of Pittsburgh Press, 1991.

Keren Kayemeth LeIsrael Jewish National Fund, last modified 2012, http://www.kkl.org.il/eng.

Krausz, Franz (Israeli artist). "The Seven-Fold Blessed Land of Israel Awaits Redemption." Poster, ca. 1935, originally published by the Jewish National fund. Accessed via the Palestinian Poster Project Archive, http://www.palestineposterproject.org/poster/ blessed-land-of-israel-awaits-redemption.

Kunzle, David. "Protest, Political." In New Dictionary of the History of Ideas Volume 3, edited by Maryanne Cline Horowitz. Detroit: Charles Scribner's Sons, 2005.

Lemon Tree. Directed by Eran Riklis. Israel: Heimatfilm/MACT Productions/Eran Riklis Productions/Riva Filmproduktion, 2008.

Maksoud, Clovis. Introduction to Palestine Lives: Interviews with Leaders of the Resistance, by the Palestine Research Center and Kuwaiti Teachers' Association, 5-25. Beirut: Palestine Research Center and Kuwaiti Teachers' Association, 1973.

Mannes, Aaron. Profiles in Terror: The Guide to Middle Eastern Terrorist Organizations. Maryland: Rowman and Littlefield, 2004.

Nadir.org. "Jihad Mansour [Marc Rudin] Preface." http://www.nadir. org/nadir/initiativ/rev_linke/sanat/jihad/jihad.htm.

Nadir.org. "Jihad Mansour [Marc Rudin]." http://www.nadir.org/ nadir/initiativ/rev_linke/sanat/jihad/jihad1.html.

Nadir.org. "Jihad Mansour [Marc Rudin]." http://www.nadir.org/ nadir/initiativ/rev_linke/sanat/jihad/jihad2.html. 
Nicola, Kamal. "Land Day." Poster, 1981, originally published by the Popular Front for the Liberation of Palestine. Accessed via Palestinian Poster Project Archive, http://www. palestineposterproject.org/poster/land-day-pflp.

Palestine Research Center and Kuwaiti Teachers' Association. Palestine Lives: Interviews With Leaders of the Resistance. Beirut: Palestine Research Center and Kuwaiti Teachers' Association, 1973.

Palestinian Food. Facebook page. https://www.facebook.com/pages/ Palestinian-Food/172565586133197.

Popular Front for the Liberation of Palestine, last modified 2011, http://pflp.ps/english/.

Popular Front for the Liberation of Palestine, "Platform of the Popular Front for the Liberation of Palestine (1969)," last modified 2011, http://pflp.ps/english/1969/12/platform-of-thepopular-front-for-the-liberation-of-palestine-1969.

Qumsiyeh, Mazin. "Palestinian Olives," last modified October 20, 2009, http://sabbah.biz/mt/archives/2009/10/20/palestinianolives/.

Rudin, Marc. "Martyr's Day." Poster, 1985, originally published by the Popular Front for the Liberation of Palestine. Accessed via Palestinian Poster Project Archive, http://www. palestineposterproject.org/poster/palestine-will-win-0.

Sahkul, Kahraman. "Abdulhamid I." In Encyclopedia of the Ottoman Empire, edited by Gábor Ágoston and Bruce Masters, 5-6. New York: Facts on File, Inc., 2009.

Seger, Markus. "Great Designers \# 1: Marc Rudin aka Jihad Mansour." http://markseger.com/?p=795.

Stratford, Charles. "Olive Harvest Reaps Animosity in West Bank." Al Jazeera English, last modified 


\section{Agriculturally Imagined Communities in}

\section{Palestine-Israel}

October 11, 2011, http://www.aljazeera.com/news/ middleeast/2011/10/20111011111235520439.html.

Swedenburg, Ted. Memories of Revolt: The 1936-1939 Rebellion and the Palestinian National Past. Fayetteville: The University of Arkansas Press, 2003.

Tannahill, Reay. Food in History. London: Review, 2002.

Visser, Margaret. Much Depends on Dinner. Toronto: McClelland and Stewart Weidenfeld.

Walsh, Dan. "Palestinian Poster Project Archives," last modified 2012, http://www.palestineposterproject.org.

Zak, David. (Israeli artist). "From a Wasteland to a Settlement." Poster, ca. 1935, originally published by the Jewish National Fund. Accessed via the Palestinian Poster Project Archive, http:// www.palestineposterproject.org/poster/from-a-wasteland-to-asettlement. 